ISSN : 2550-0198

\title{
PELATIHAN HEAT TREATMENT SEDERHANA UNTUK SISWA SMK SE-PEKANBARU
}

\author{
Budi Istana, Sunaryo, Ahmad Kafrawi Nasution, Abrar Ridwan, Legisnal \\ Hakim, Lega Putri Utami \\ Prodi Teknik Mesin, Fakultas Teknik \\ Universitas Muhammadiyah Riau \\ *Email: budiistana@umri.ac.id
}

\begin{abstract}
Abstrak
Industri pengecoran logam umumnya menggunakan baja karbon sebagai bahan baku utama. Hal ini disebabkan oleh besarnya kebutuhan industri terutama industri pengolahan kelapa sawit, kertas dan industri lainnya terhadap komponen mesin yang diproduksi dengan teknik pengecoran logam. Banyak dipakainya baja karbon pada industri tersebut mengakibatkan bahan tersebut harus mengalami penyesuaian pada sifat mekanis yang diinginkan oleh pemakainya, salah satu langkah yang dapat diambil adalah dengan melakukan proses perlakuan panas, proses ini akan sangat bergantung pada komposisi kimia bahan, suhu pemanasan, waktu penahanan (hold time) dan kecepatan pendinginan (cooling rates). Kegiatan Pengabdian ini bertujuan untuk memberikan pengetahuan kepada siswa SMK di lingkungan kampus tentang pengaruh proses pendinginan paska perlakuan panas terhadap sifat mekanik logam terutama nilai kekerasannya. Kegiatan ini diharapkan dapat menjadi motivasi bagi siswa dalam mempelajari ilmu metalurgi.
\end{abstract}

Kata kunci: perlakuan panas, cooling rates, sifat mekanik, siswa SMK

\section{PENDAHULUAN}

Sejak zaman dulu metode heathreatment telah digunakan oleh orang-orang untuk mengubah sifatsifat mekanik logam sesuai dengan keinginannya, contohnya dalam pembuatan alat-alat perang seperti ujung tombak pedang serta tameng. Ini menunjukan bahwa heathreatment adalah metode paling mudah dan baik yang dapat digunakan mengubah sifat-sifat mekanik dari suatu material. Pada zaman dahulu logam yang baik dianggap adalah logam yang keras dan kuat karena penggunannya hanya semata untuk peralatan peralatan yang sederhana seperti pedang, ujung tombak dan yang lainnya. Oleh karena itu metode perlakuan panas yang digunakan belum bervariasi, nanti kemudian dizaman moderen ketika qualitas logam tidak hanya diukur dari kekuatan dan kekerasaanya tetapi dari terpenuhinya sifat-sifat mekanik lain yang sesuai dengan kebutuhan, baru kemudian berkembang metodemetode Heathreatment untuk menghasilkan sifat-sifat mekanik yang dibutuhkan.

Sekarang metode heat threatment masih merupakan metode yang paling baik yang dapat digunakan untuk mengubah sifat-sifat mekanik suatu material logam. Dengan heathreatment kita dapat meningkatkan ataupun menurunkan sifat-sifat dari logam sesuai dengan kebutuhan akan sifat mekanik logam tersebut yang kita butuhkan. 
Pesatnya laju pembangunan dan teknologi yang semakin moderen sekarang ini mendorong naiknya tingkat kebutuhan akan logam dengan berbagai macam karakteristik yang sesuai dengan tujuan penggunaannya. Hal ini juga mendorong berkembangnnya variasi metodemetode Heathreatment untuk menghasilkan sifat-sifat dari logam yang sesuai dengan kebutuhan dunia industri moderen saat ini.

\section{METODE PENGABDIAN}

Metode yang digunakan dalam kegiatan pengabdian ini adalah menggunakan metode ceramah, diskusi dan praktek. Peserta diberikan pemahaman dasar tentang perlakuan panas pada logam dan mempelajari tentang klasifikasi jenis perlakuan panas.setelah peserta dapat memahami dasar teori selanjutnya peserta diajak untuk mempraktekkan secara langsung proses perlakuan panas pada logam, pengukuran nilai kekerasan sehingga didapat hasil pengujian lalu dilanjutkan ketahap analisa hasil pengukuran kekerasan logam.

\section{HASIL DAN PEMBAHASAN}

Kegiatan pengabdian ini di isi dengan ceramah, diskusi dan tanya jawab serta praktek secara kelompok.

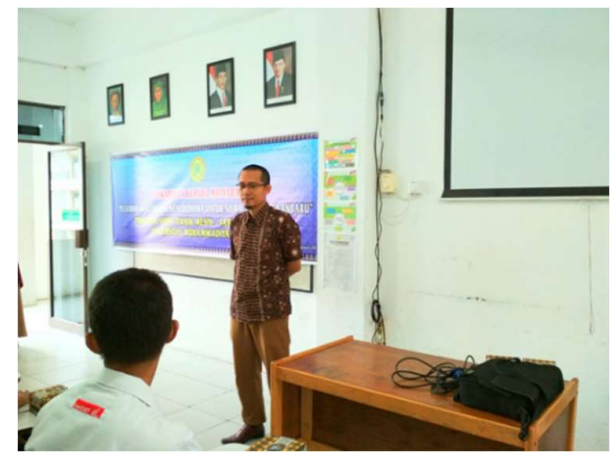

Gambar1. Penyampaian materi pertama

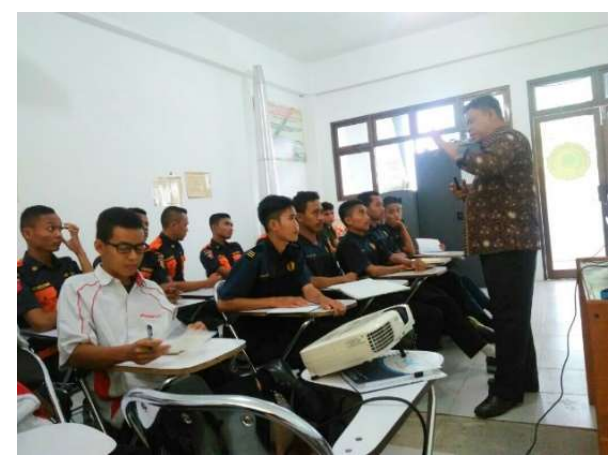

Gambar 2. Penyampaian materi Kedua

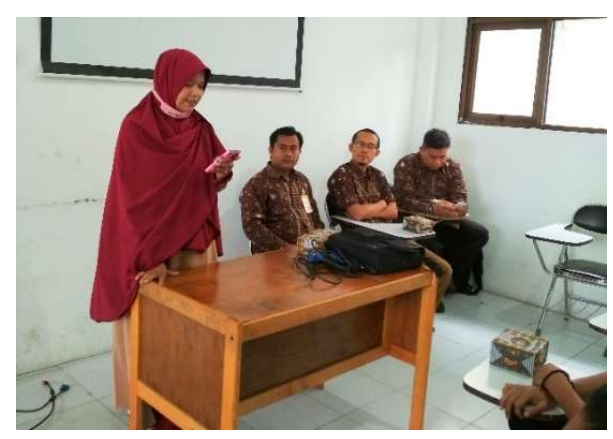

Gambar 3 Penyampaian materi Ketiga 
ISSN : 2550-0198

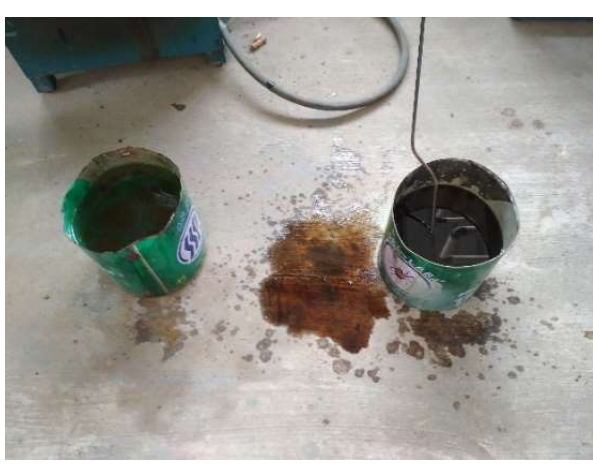

Gambar 4. Fluida yang digunakan untuk mendinginkan logam hasil perlakuan panas.

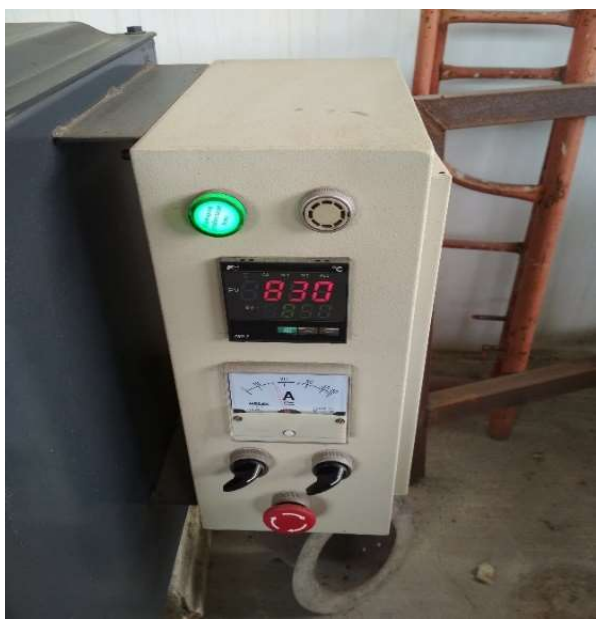

Gambar 5. Tungku Perlakuan panas, tampak pada gambar specimen uji akan dipanaskan hingga temperature 850 oC.

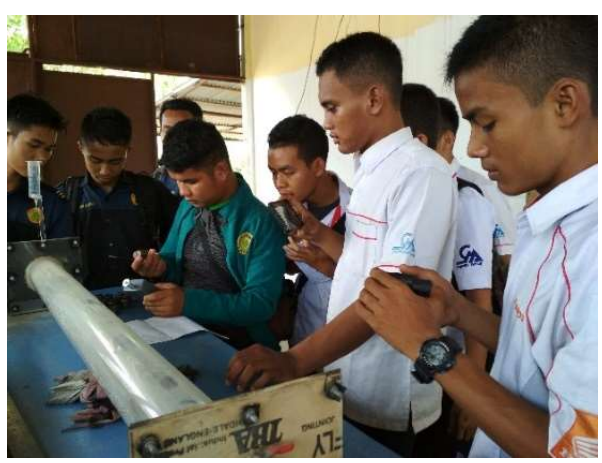

Gambar 6. Peserta Pelatihan.

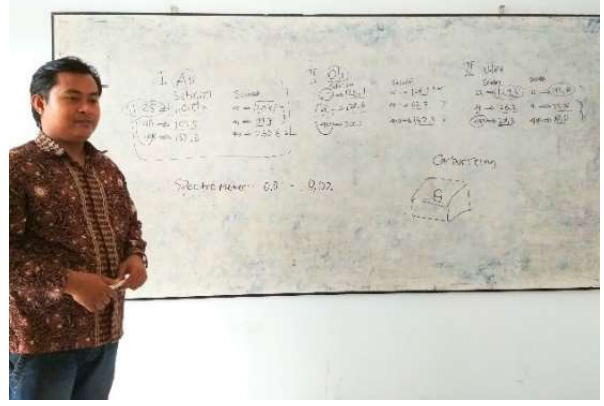

Gambar 7. Penyampaian teori teknik penggunaan tungku, penggunaan alat ukur dan teknik analisa data oleh Bapak Budi Istana, SST., M.Eng

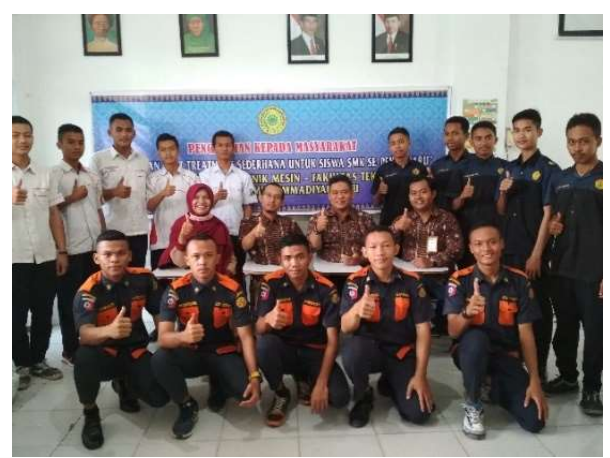

Gambar 8. Foto bersama saat pembukaan dan penutupan kegiatan.

\section{SIMPULAN}

1. Peserta pelatihan telah memiliki pengetahuan dalam perlakuan panas pada logam.

2. Peserta pelatihan telah memiliki keterampilan dalam perlakuan panas pada logam

3. Peserta pelatihan telah memahami bahwa logam dapat di tingkatkan kekuatan sifat mekaniknya.

\section{UCAPAN TERIMAKASIH}

Terima kasih sebesar-besarnya kepada Lembaga Penelitian dan Pengabdian masyarakat (LPPM) UMRI atas bantuan dana dan fasilitas 
kegiatan pengabdian bagi Program Studi Teknik Mesin, serta kepada Kepala Sekolah SMK Masmur, Kepala SMK Taruna Satria dan SMK Muhammadiyah 3 Pekanbaru atas partisipasinya dalam mengirimkan siswanya untuk diberikan pelatihan ini.

\section{DAFTAR PUSTAKA}

[1] Rubijanto, pengaruh proses pendinginan paska perlakuan panas terhadap uji kekerasan ( vickers ) dan uji tarik pada baja tahan karat 304 produksi pengecoran logam di klaten, 2006 TRAKSI.

[2] Yani, Rina Dwi Pratomo, Tri Cahyono, Hendro, Pengaruh Perlakuan Panas Terhadap Struktur Mikro Logam St 60, 2008 [2] Dewan Standar Akuntansi Keuangan. (2009). StandarAkuntansi Keuangan Entitas Tanpa Akuntabilitas Publik. IkatanAkuntan Indonesia. Jakarta.

[3] Santosa, Irfan, Pengaruh Perlakuan Panas Terhadap Kekuatan Tarik Dan Ketangguhan Impak Pada Baja ST, 2008, OSEATEK.

[4] B. Anwar; Analisis Perbedaan Kekerasan Baja Steel (St) 60 yang Didinginkan dengan Menggunakan Air dan Oli Setelah Proses Perlakuan Panas, 2011.

[5] J. Ilyas; A. Haryadi; analisa pengaruh perlakuan panas terhadap kekuatan sambungan las baja karbon tinggi, 2012
[6] Surdia, Tata. Teknik Pengecoran Logam. Jakarta : Pradnya paramitha 1996

[7] Supardi, Edih. 1999. Pengujian Logam. Bandung: Angkasa.

[8] Van Vlack, Lawrench. 1985. Ilmu dan Teknologi Bahan (ilmu logam dan bukan logam). Jakarta : Erlangga. 